\title{
DYNAMIC PRIORITIZATION OF SHIPMENTS IN AN AGRICULTURAL FERTILIZER COMPANY USING AHP AND TOPSIS
}

\begin{abstract}
Inside of logistics operations the inventory as a distribution resource does a very important role of generation of value for companies, so the decisions made in each shipment to a distribution center could affect the level of service, finances (working capital) owing to the movement of inventory between distribution centers, slow moving inventory and lost sales. This study shows a dynamic planning of shipments from an agricultural fertilizer producing plant to its distribution centers around the country (Colombia) using the MCDA tools such as AHP and TOPSIS from logistics indicators, one sales indicator and one financial indicator.
\end{abstract}

Keywords: Logistics, planning, inventory, shipments, AHP, TOPSIS.

\section{Introduction}

Commonly, the transport management is limited to vehicles availability and their characteristics (size, capacity, kind of bodywork), transport costs and the choice of the best route. However, the inventory, the availability, and the needs of the users (customers and distribution centers) and the performance measured with indicators as criteria to prioritize and make a shipment are not used regularly. The distribution resources such as limited inventory to satisfy high levels of service have caused the need to generate priorities in the shipments from factories or main warehouse to their trading partners.

This study was made in a company that produces and trades agricultural fertilizer, with an "anchor item" whose sales and units increased 32\% in 2019 (\$744MM COP) and 24\% (8557 units) compared to the previous year. Therefore, it's particularly important to manage these kinds of items so that the only way out is not to increase inventory without reason. Front a limited resource is necessary to use tools that improve the distribution management satisfying at right place, right time, right quantity, ensuring the sustainability and profitability of the operations.

\section{Literature Review}

Since the study done for (Bravo et al;, 2007) started to propose the use of logistics indicators to prioritization in transportation, then in 2009 with the work (Bravo et al, 2009) the incorporation of the AHP methodology under dynamic prioritization using the logistics indicators previously referred. (Hernandez et al, 2017) made a deeper study about dispatch prioritization using fuzzy AHP applied to logistics indicators as criteria and TOPSIS to rank the alternatives (customers or distribution centers) and finally (Osorio et al, 2018) extended to the fuzzy QFD to stablish the order of shipments of the finished goods. 


\section{Hypotheses/Objectives}

The objectives of the study are define criteria to planning shipments of finished goods (item analyzed). For this, that idea is to rank the higher criteria trough AHP and to establish the alternatives (distribution centers) to ship the finished good trough of TOPSIS.

list them here. The reader must be clear about the specific objectives or hypotheses in your study.

\section{Research Design/Methodology}

We propose the use of AHP and TOPSIS. The team aiming rate the criteria each other according (Saaty, 1987) and ranked the higher criteria trough AHP, after with TOPSIS establish the priority distributions centers to dispatch. See Fig 1.

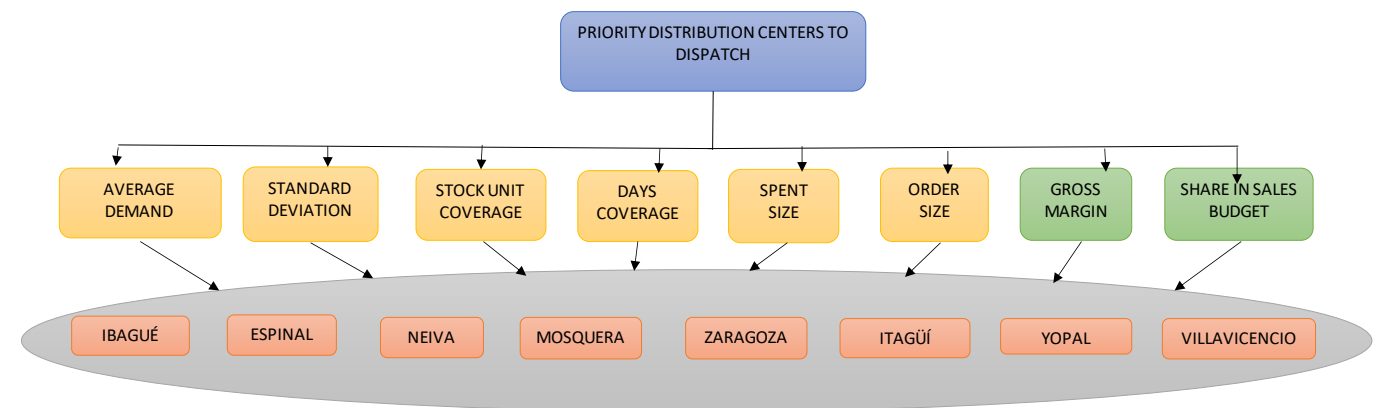

Figure 1. The proposed decision-making structure for dispatch

\section{Data/Model Analysis}

Table 1 presents the data to application. And Table 2 shows the results of the proposed methodology. Finally, the TOPSIS outcome shows to distribution center in Ibagué with a closeness coefficient of 0.72 like the first destiny to dispatch, followed for Mosquera (0.69) and Yopal (0.63).

\section{Limitations}

This work is applied only to a special item characterized like an "anchor product". However, it has the potential to be applied to others special items, it can be used as a complete shipment planning tool.

\section{Conclusions}

The above contribuiton describes the main criteria used during a real shipments planning process and which are the most important according to the judgements of experts. The combination of both the AHP and TOPSIS methods offer a robust tool to select the priority destinations but are also user-friendly for people who unfamiliance don't know MCDA through spreadsheets applications. 
ISAHP Article: A Style Guide for Paper Proposals To Be Submitted to the International Symposium on the Analytic Hierarchy Process 2020, Web Conference.

Table 1. Data to case of study

\begin{tabular}{|l|c|c|c|c|c|c|c|c|}
\hline $\begin{array}{c}\text { Unified matrix } \\
\text { trough geometric } \\
\text { mean }\end{array}$ & $\begin{array}{c}\text { Average } \\
\text { demand }\end{array}$ & Standard deviation & $\begin{array}{c}\text { Stock unit } \\
\text { coverage }\end{array}$ & $\begin{array}{c}\text { Days } \\
\text { coverage }\end{array}$ & $\begin{array}{c}\text { Spent } \\
\text { size }\end{array}$ & Order size & Gross margin & Share in sales \\
\hline Average demand & 1,00 & 0,39 & 0,38 & 0,72 & 0,17 & 0,61 & 0,49 & 0,19 \\
\hline Estándar deviation & 2,58 & 1,00 & 1,47 & 0,72 & 0,68 & 1,05 & 0,48 & 0,58 \\
\hline Stock unit coverage & 2,62 & 0,68 & 1,00 & 0,80 & 0,61 & 0,63 & 0,80 & 2,81 \\
\hline Days coverage & 1,38 & 1,38 & 1,25 & 1,00 & 0,58 & 0,48 & 2,22 & 0,60 \\
\hline Spent size & 5,81 & 1,47 & 1,63 & 1,72 & 1,00 & 3,50 & 2,37 & 1,10 \\
\hline Order size & 1,63 & 0,95 & 1,58 & 2,07 & 0,29 & 1,00 & 1,37 & 0,64 \\
\hline Gross margin & 2,03 & 2,07 & 1,37 & 0,45 & 0,42 & 0,72 & 1,00 & 0,37 \\
\hline Share in sales & 5,16 & 1,72 & 0,36 & 1,66 & 0,90 & 1,55 & 2,71 & 1,00 \\
\hline
\end{tabular}

Table 2. Results of the prioritization

\begin{tabular}{|c|c|}
\hline Ibagué & 0,72 \\
\hline Mosquera & 0,69 \\
\hline Yopal & 0,63 \\
\hline Medellín & 0,57 \\
\hline Espinal & 0,53 \\
\hline Zaragoza & 0,45 \\
\hline Neiva & 0,39 \\
\hline Villavicencio & 0,37 \\
\hline
\end{tabular}

With the weak economies by the pandemic, the companies should appropriate of systems or methods that help them to generate value, resilience, security, taking advantage a best management of their current resources and the MCDA tools are an amazing example to apply.

\section{Key References}

Bravo et al;. (2007). Administración de recursos de distribución: Indicadores para la priorización en transporte. Estudios Gerenciales Vol. 23 No. 102, 109-110.

Bravo et al. (2009). Dynamic priorization model of dispatching vehicles using analytic hierarchy process. Engineering Faculty of UDEA (48), 201-215.

Hernandez et al. (2017). Disptach prioritization using fuzzy AHP and Topsis. Tecnura, 21(52), 102-110.

Osorio et al. (2018). Prioritization of Deliveries in Manufacturing Companies Using Fuzzy QFD. Engineering review University of Medellín, 17(33), 173-186

Saaty. (1987). THE ANALYTIC HIERARCHY PROCESS-WHAT IT IS AND HOW IT IS USED. Mathl Modelling, 161-176. 